\title{
Kamu Yönetiminde Geleceğin İnşasında Stratejik Bakış
}

\begin{abstract}
Ahmet GÜVEN*
Özet

Günümüzde kamu yönetiminin artan rekabet ortamıyla birlikte mevcut sorunlarından kurtulmak ve etkin hizmet sunabilmek için yeni arayışlar içinde bulunduğu bilinmektedir. Bu doğrultuda kamu yönetiminde öne çıkan strateji, stratejik yönetim ve stratejik bakış gibi kavramların öneminin hızla artığg görülmektedir. Bu çalışmada kamu yönetiminin geleceğinin şekillenmesinde stratejik yönetim anlayışının kamu kurumlarında uygulanması gerekliliği üzerinde durulmaktadır. Bu kapsamda çalışmada ilk olarak strateji olgusu ele alınmaktadır. Ardından kamu yönetiminin sorunları ve gelecek endişesi konularına yer verilmektedir. Son olarak kamu yönetiminin yüz yüze kaldı̆̆ı sıkıntı ve endişeler karşısında bir çözüm aracı olarak öne çıkan stratejik bakış konusu değerlendirilmektedir.
\end{abstract}

Anahtar Kelimeler: Kamu yönetiminin inşası, bürokratik sorunlar, stratejik yönetim, stratejik bakış,

\section{Strategic View in Building the Future of Public Administration}

\section{Abstract}

The public administration today is known to be in new searches to get rid of its existing problems and to provide effective services with an increasing competitive environment. In this direction, it is seen that prominent concepts such as strategy, strategic management and strategic view in public administration are increasingly becoming important. This study focuses on the role of implementing strategic management approach in public institutions on shaping the future of public administration. In this context, first of all, strategy is discussed as a fact. Second, the problems and future concerns of the public administration are analyzed. Finally, the issue of strategic view is evaluated as a solution for the difficulties and concerns of public administration.

Key Words: Construction of public administration, bureaucratic problems, strategic management, strategic view.

* Yrd. Doç. Dr., Gaziosmanpaşa Üniversitesi İktisadi ve İdari Bilimler Fakültesi Kamu Yönetimi Bölümü, e-posta: ahmetguvenn@gmail.com 


\section{Giriş}

Kamu yönetimi, bilgi çağı ile birlikte yıllardır Weberyen bürokrasi anlayışı kapsamında içine çekildiği kabuğundan sıyrılarak, toplumun kendisinden beklediği işlevsel yönetimi sağlayabilmek ve bu anlamda kendisi ve özel sektörle rekabet edebilir bir yapıya kavuşmak için gayret göstermiştir. Kamu yönetiminin toplumsal sorumlulukları yerine getirmesi, ileriyi gören bir yönetim anlayışına sahip olmasını gerektirmiştir. Özel sektör yıllardır kar sorununu çözmek için stratejik yönetim metotlarından yararlanmıştır. Kamu yönetimi ise klasik anlayışın yükleri altında ezilmekten bir türlü kurtulamamış; özel sektör bir yana kendi içersinde bile rekabet edememiştir. Oysa küreselleşme olgusu ile küçülen dünyada kamu yönetiminin artan görev ve işlevleri, kamu yönetiminin önemini çok daha fazla artırmıştır.

Günümüzde tüm dünyada artan rekabet olgusu, stratejik yönetim anlayışının önemini her gecen gün daha fazla hissedilir hale getirmiştir. Sadece özel sektör de değil kamu ve kar amacı gütmeyen üçüncü sektör örgütleri de küreselleşmeyle ortaya çıkan rekabet ortamında stratejik düşünme ve stratejik karar alma ihtiyacı hissetmişlerdir(Aktan,2003:67). Bu sebeplerden dolayı stratejik yönetimin bir unsurunu oluşturan stratejik bakış olgusu, kamu yönetiminde yönetimin üzerinde önemle durması gereken bir konuyu oluşturmuştur.

$\mathrm{Bu}$ doğrultuda hazırlanan çalışmada, tarama modelinden faydalanılarak betimsel bir yol izlenmiştir. Bu kapsamda özellikle son dönem kamu yönetiminde gözlenen bürokratik sıkıntılar, yönetimin/yöneticilerin karşılaştıkları yönetsel sorunlar; yeni kamu yönetimi yaklaşımı içinde özelde stratejik yönetim temelli teorik ve ampirik literatüre dayanılarak, çözüme kavuşturulması amaçlanmıştır. Bu çalışmada kamu yönetiminde bürokrasiden kaynaklanan sorunlardan hareketle; stratejik yönetimin bir aracı olan stratejik bakışın kamu yönetiminde önemi ve gerekliliği üzerinde durulmuştur. Yine bu çalışmayla kamu yönetiminin işlevsel ve etkin hizmet sunumunda bu araçtan faydalanmasının kamu yönetiminin hedeflerine ulaşmasında, halkın beklentilerine yerinde ve zamanında cevap vermesinde önemli bir işlevi olduğu yönündeki düşünceler değerlendirmeye çalışılmıştır. Çalışmada stratejik yönetim ve stratejik bakış olgusu ile ilgili kavramlar değerlendirilerek kamu yönetiminin temel sorunlarını oluşturan bürokrasi içerikli problemlerden kurtulmada stratejik bakışın rolü ve stratejik düşünme yeteneğine sahip yöneticilerin önemi vurgulanarak, geleceğin kamu yönetiminin inşasında stratejik bakışın gerekliliği konusu işlenmiştir. Bu kapsamda; Kamu yönetiminin temel sorunlarının çözümünde yöneticilerin stratejik bakışa sahip olması sorunların çözümünde etkili midir? Kamu yönetimi mevcut sorunlarından bu yöntemle kurtulabilir mi? Kamu yönetiminin gelecek inşasında stratejik bakışın yeri ne olacaktır? Sorularına kapsamlı ve sistematik bir şekilde tanımlama, çözüm ve tavsiyeler sunularak cevaplar aranmıştır.

\section{Kavramsal Çerçeve}

\section{Strateji Olgusu}

Strateji kavramı, askeri bir terim olarak generallerin askeri eylemlerde uyguladıkları sanatı ifade eden "strategos" sözcügü ile özdeş Yunanca bir kavramdır(Luecke, 2008: XII.). Strateji 
kavramının bu dilde "stratos" (ordu) ve "ago" (yönetmek) kelimelerinin birleşmesinden oluştuğu düşünülmektedir. Daha çok askeri terminolojide kendine yer bulan strateji sözcüğü, zaman içinde yönetim alanında da kullanılmaya başlamıştır(Söyler, 2007:104). Strateji kavramı, stratejik karar verme ve buna bağlı olarak organizasyonların misyon, vizyon ve amaçları doğrultusunda gerekli kaynakları her zaman hazır bulundurarak rakiplerinin önünde yer almasını sağlayan yeni stratejileri geliştirebilecek pozisyonda tutmayı hedefleyen birikimsel bir süreci ifade etmektedir(Yüzbaşıŏlu, 2004b: 87-88). Strateji, ileriye yönelik politikaları üretme, güçlü olma, güçleri birleştirme, amaç ve araç uygunluğu sağlama, mevcut güçlerin etkin kullanımını sağlama, esnek ve tedbirli olma gibi ilkelerden oluşan bir yönetim anlayışını ifade etmektedir(Bircan,2002:13). Strateji, bir kurumun farklılık yaratarak rakipleri karşısında avantaj sağlama planını ifade etmektedir. Strateji, nerede olduğumuzu ne yapmak istediğimizi hedeflerimize nasıl ulaşacağımızı gösteren bir bakış açısıdır(Luecke, 2008: XV.). Stratejinin temel amacı, kurumların kaynak ve kabiliyetleri ölçüsünde çevreye duyarlılığı sağlamaktır. Strateji; sürekli değişen, belirsiz ve dolayısıyla riskli olan çevre koşulları karşısında kurumların işlerliğine yön kazandıracaktır. Bu açıdan bakıldığında kurumların başarısızlıklarının önündeki en büyük engelin strateji yokluğu veya strateji yanlışlığından kaynaklandığı görülmektedir(Gürer,2006:94). Strateji bir kurumun mevcut durumundan hareketle ne olduğu, ne yaptığı ve niçin yaptığını belirleyen kararları oluşturmaktadır(Söyler, 2007:107).

Strateji kavramı, günümüzde hemen hemen her sektörde kullanılan; adından sıkça söz edilen bir kavram haline gelmişsir. Strateji kavramı askeri alanda stratejik hareket etmeyi ifade eden bir kavram olarak ortaya çımıştır. Daha sonra yönetim alanında özel sektör örgütlerinde, şirketlerin daha fazla kar elde etmesi, rakiplerine fark atması, uygulayacakları politikaları bu amaçlara göre belirlemesini sağlayan kararlar ve hedefler olarak kendine yer bulmuştur. Günümüzde ise kamu sektörü ve kar amacı gütmeyen sektörlerde etkinlik, verimlilik ve kalite anlayışı çerçevesinde toplumun beklentilerine cevap veren politika ve eylemlerin geliştirilmesinde önemli bir araç olarak kendine yer bulduğu görülmektedir.

\section{Stratejik Planlama}

Stratejik yönetimin en önemli aşamasını stratejik planlama aşaması oluşturmaktadır (Yüksel,2004:43). Stratejik planlama; örgütün ne olduğu, ne yaptı̆̆ı ve neyi neden yaptı̆̆ına açılama getiren ve yol gösteren temel stratejiler ve eylemleri belirlemek için disipline edilmiş bir çabadır(Bryson, 1995: 4). Stratejik planlama bir örgütün günlük faaliyetlerine yön ve anlam sağlayan bir araç olup örgütün değerlerini, mevcut durumunu ve çevresini değerlendirip bu faktörleri örgütün arzulanan gelecek durumuyla ilişkilendirerek başarılı bir yönetim anlayışına sahip olmasına katkı sağlamayı amaçlamaktadır(Gürer,2006:91). Stratejik planlama, örgütün amaçlarını belirleme süreciyle başlayarak alternatif stratejilerin geliştirilmesi aracılığıyla örgütün amaçlarına ulaşılmasında kullanılacak stratejilerin belirlenmesini ifade etmektedir(Yüzbaşığlu,2004b:91).

Stratejik planlamanın özel sektörde 1950 'li yıllardan itibaren örgütlerin kendi güçlü ve zayıf yönlerini, dış çevrede meydana gelen olayları, tehdit ve firsatları sürekli olarak analiz ederek 
örgütlerin verimliliğini ve etkinliğini artırmak amacıyla kullanıldığı gözlenmektedir. Kamu yönetimindeyse stratejik planlamanın klasik anlayışın ağırlığını azaltmaya başladığı 1980'li yıllardan itibaren kendine yer bulmaya başladığı görülmektedir(Genç,2009:201). Stratejik planlamanın, kamu yönetiminde ve kar amacı gütmeyen örgüt lider ve yöneticilerine öğrenme, düşünme ve strateji geliştirme konularında yardım edeceği düşünülmektedir.(Bryson, 2011:1)

Stratejikplanlama, kamu kurumlarının katılımcıve esnek bir planlama yaklaşımıbenimseyerek kurumların mevcut durum, misyon ve temel ilkelerinden hareketle geleceğe dair bir vizyon oluşturmaları, bu vizyona uygun hedefler saptamaları ve ölçülebilir göstergeler geliştirerek, başarıyı izlemeleri ve değerlendirmelerinde bir araç olarak kullanılmaktadır(Yılmaz,2003:77).

Stratejik planlama, kamu kurumlarının misyonu çerçevesinde gelecekteki vizyonuna ulaşmak için amaçlar, hedefler ve bunlara ulaşmayı sağlayacak faaliyet ve projeler kapsamında bütçelerinin ayarlanmasından faaliyet ve projeler, performans göstergeleri ile sürekli bir izleme ve değerlendirme sürecine kadar kurumun hedef ve amaçlarına ulaşmayı sağlayacak politikaları kapsayan bir süreçtir(Akçay,2009:30). Stratejik planlama bir defaya mahsus bir işlem değildir; ortaya çıkan firsatlara göre tekrarlanan bir süreci ifade eder. Bu nedenle kamu kurumlarında sadece stratejik planlama yapmak yeterli değildir. Etkin bir yönetim için stratejik plan yapmanın yanında, yöneticilerin stratejik düşünme ve vizyon geliştirme niteliklerinin güçlendirilmesi de gerekmektedir(Yilmaz, 2003:76).

Stratejik planlama süreciyle bir kuruluşun Şekil 1.'deki dört temel sorusuna yanıt araması beklenmektedir(DPT,2006:8).

Şekil 1. Stratejik Planlama Süreci

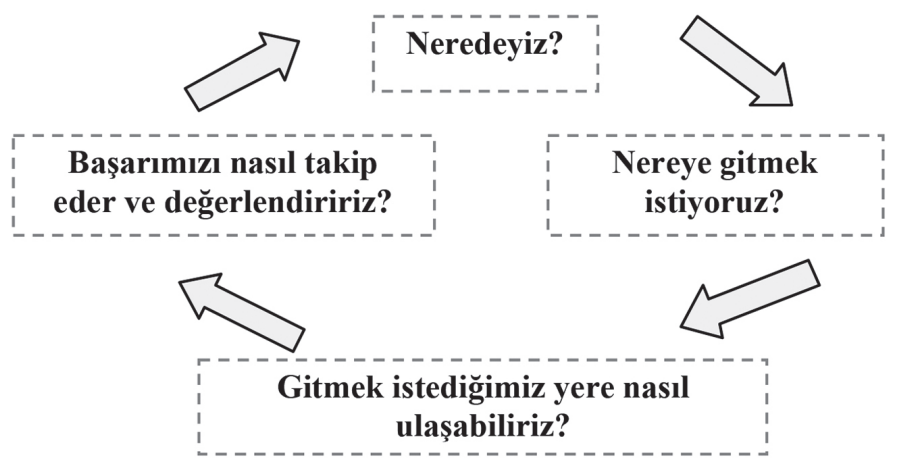

Stratejik planların oluşturulması sürecinde, stratejik planların etkin oluşturulabilmesi için, yöneticilerin vizyon sahibi, ileriyi gören kurumun mevcut durumu ve gelecekte karşı karşıya kalabileceği durum ve koşulları öngörebilen bir nitelik taşıması, hazırlanacak olan stratejik planların amacına uygunluğu ve etkinliği üzerinde önemli bir etkiye sahip olacağ1 düşünülmektedir. 
Stratejik planlar hazırlanırken çok sayıda farklı yöntem kullanılabilir. Bunlardan bir tanesi Bryson tarafından geliştirilen ve Şekil 2.'de gösterilen Rasyonel Planlama Modelidir.

\section{Şekil 2. Rasyonel Planlama Modeli}

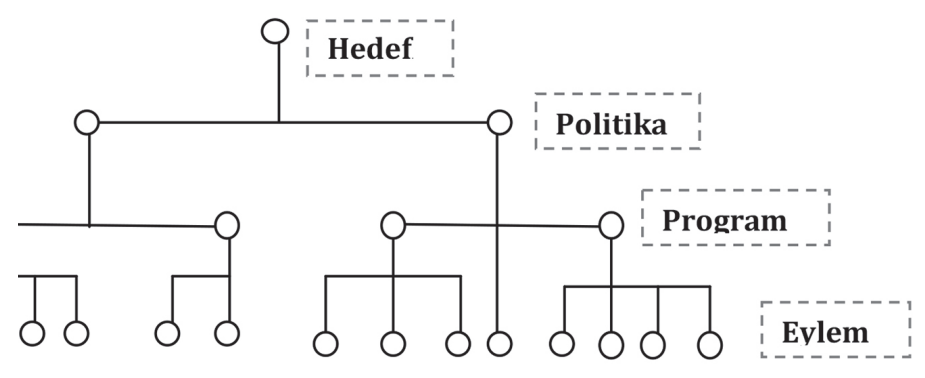

Kaynak: (Bryson 2011: 22) Şekil, Bryson'dan uyarlanmıştır.

Bryson'a göre tümden gelimci bir yol izleyen rasyonel planlama modeliyle stratejik planlar belirlenen hedef/amaçlardan hareketle politika belirleme, program geliştireme ve eyleme dönüşme şeklinde kuramsal bir yapıyla ifade edilmeye çalışılmaktadır(Bryson, 2011: 22). Bu kapsamda kamu kurumları stratejik planlarını; oluştururken şu süreci izlemelidirler; öncelikle hedeflerini belirlemeli, bu hedefler doğrultusunda politikalar geliştirmeli, politikaların nasıl uygulandığını gösteren programlar saptamalı ve bu programlar kapsamında eylemlerle harekete geçmelidirler.

Stratejik planlar hazırlanırken kamu kurumları durum analizi, kurum içi ve çevre analizleri kapsamında başlıca; strateji geliştirme teknikleri olarak; SWOT Analizi, Pörtföy Analizleri, Q-Sort Analizi, Senaryo Analizi, Vizyon/Mizyon, Arama Konferansı, Delphi Tekniği, Nominal Grup, Multivoting, Açık Grup, Kalite Çemberleri, Fayda-Maliyet, Risk Analizi gibi analizlerden faydalanması gerekmektedir(Aktan,2008,7-9).

$\mathrm{Bu}$ analizler arasında en popüler olanı; SWOT Analizi adı verilen ingilizce "strength" (güçlü yönler), "weakness"(zayıf yönler), “opportunity" (firsatlar), "threat" (tehdit ve tehlikeler) kelimelerin baş harflerinden oluşan analiz tekniğidir(Aktan,2003:73). SWOT Analiziyle kurumların geçmişten geleceğe uzanan trendleri göz önüne alındığında, kurumun mevcut/ umulan durumunun rekabetçi yanlarıyla ile rekabet karşısında karşı karşıya kaldığı dezavantajlı zayıf yönü yanı sıra yapısal değişimler sonucunda ortaya çıkabilen/çıkan tehdit ve fırsatlar tespit edilmeye çalışılmaktadır(Barca vd.,2006:35).

Yine örgütler stratejik planlarını hazırlarken Balanced Scorecard gibi farklı tekniklerden de yararlanabilirler. Bu kapsamda örgütlerin, a)finansal boyutu, b)müşteri boyutu, c)işletme içi süreçler boyutu ve d)öğrenme-gelişme boyutu açısından farklı değerlendirmelere tabi tutulması 
gerekebilir(Kaplan ve Norton, 1996:2) Birçok örgüt tarafından strateji belirlemek, strateji uygulamak amacıyla kullanılan Balanced Scorecard örgütlerin uzun dönemli başarısında Kaplan ve Norton ifade ettiği gibi dört boyutun bir denge içerisinde ele alınmasıyla söz konusu olacağ 1 düşünülmektedir(Kaplan ve Norton,2009)

Kamu kurumlarında stratejik planlama 25 yılı aşkındır uygulanmaya çalışılsa da 2020'li yıllarda kamu kurumlarında stratejik planlamanın şimdiye göre çok daha kritik rol alacağ düşünülmektedir(Poister, 2010: 248). Kavram kargaşasına yer vermemek için "stratejik planlama” ve "stratejik bakış" kavramı makalede geniş anlamda "stratejik yönetim” sürecinin bütününü kapsayacak şekilde kullanılmıştır.

\section{Stratejik Yönetim}

Stratejik yönetim, strateji olgusu kapsamında örgütlerin ya da kurumların işleyişlerinin, amaçlarının, hedeflerinin planlandığı, mevcut durumdan hareketle gelecekte ortaya çıkabilecek koşulların kestirilmeye çalışıldığı, bir yönetim sürecini ifade etmektedir. Stratejik yönetim geçmişten ziyada geleceği yönetmeyi isteyen; bu yönde kararlar alan ve uygulayan bir yönetim anlayışına sahiptir(Yüzbaşığlu,2004b:94). Stratejik yönetim kamu kurumlarında stratejik planlama, bütçeleme, personel ve performans ölçümü konularını da içinde barındıran bir nitelik göstermektedir(Bryson vd., 2010:13). Stratejik yönetim özel sektör, kamu sektörü ve kar amacı taşımayan örgütlerde geleceğe yönelik amaç ve hedeflerin belirlenmesinde ve hedeflere ulaşılması için yapılması gerekli olan işlemlerin tespit edildiği bir yönetim tekniği olarak kabul edilmektedir(Aktan, 2003: 68).

\section{Şekil 3. Stratejik Yönetimin Ana Bileşenler}
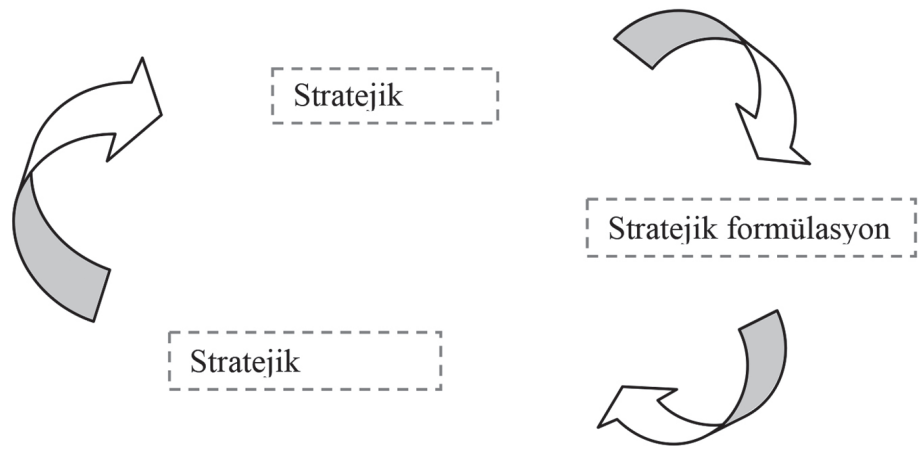

Kamu yönetiminde stratejik yönetim, (a)kurumların hedeflerine ulaşmasını sağlayacak fonksiyonel kararların kesin ve açı olarak belirlenmesi, (b)bütünlüğün tamamlanması ve değerlendirilmesi sürecine yer veren stratejik analiz, (c)strateji biçimlendirme ve uygulama 
sürecinden meydana gelmektedir (Yüzbaşığlu,2004a:389). Kamu kurumlarında uygulanmak istenen stratejik yönetim süreci; kurumun hedeflerine ulaşabilmesi için stratejik planlama yapılması, bu planın gerçekleştirilmesi için oluşturulan politikalar ve örgütsel yapı marifetiyle stratejilerin uygulanması ve tüm bu faaliyetlerin yönetim amaçları ile uygunluğunun stratejik denetimi şeklinde üç ana aşamadan oluşmaktadır(Söyler, 2007: 105).

Yine benzer bir sınıflama Dess ve Miller tarafından yapılmaktadır. Stratejik yönetimin Şekil 3.'te görüleceği üzere, stratejik analiz, stratejik formülasyon ve stratejik uygulama olmak üzere üç temel bileşenden oluşmaktadır.(Dess and Miller, 1993: 10)

Stratejik yönetim sürecini benimseyen örgütlerin başarısı, kendi stratejileri ile rakip örgütlerin stratejik temel dayanaklarını belirlemelerine bağlıdır(Yüzbaşığlu,2004b:194). Örgüt stratejileri, örgütlerin hedef ve amaçları olarak kabul edilmektedir(Nasi and Frosini, 2010:87). Bu nedenle yöneticiler, stratejik yönetim sürecinde örgütü bir bütün olarak düşünmeli, örgütün çevresi ile olan ilişkilerini ve içerisinde faaliyet gösterilen çevre koşullarını da dikkate alarak rakiplerine karşı en uygun şekilde rekabetçi üstünlüğü sağlamaya çalışmalıdırlar(Gürpınar ve Döven,2007:174). Stratejik yönetim sürecinde kurumun hedef ve amaçları doğrultusunda kurum yöneticilerine; kurumun stratejilerinin belirlenmesinden planlamaya, planlamadan denetime kadar çok sayıda önemli görevler düşmektedir.

\section{Kamu Yönetiminde Yaşanan Sıkıntılar}

Kamu yönetimi tarihsel süreç içerisinde dünyanın her yerinde gerek kendi yapısından kaynaklanan nedenlerden ötürü gerekse toplumsal ve çevresel nedenlerden dolayı çok sayıda sorunla karşı karşıya kalmıştır. Bu sorunlar karşısında bir çözüm yolu olarak her ülkenin çok sayıda reform denemesine başvurduğu gözlenmektedir. Kamu yönetiminde reform girişimleriyle yönetsel aksaklıkların ve bozuklukların giderilmesi ve yönetime yeni bir biçimin verilmesi arzulanmaktadır(Acar ve Sevinç,2005:23). Ancak arzulanan amaçlar için hazırlanan reform girişimlerinin de çok farklı sorunlara neden olduğu da bir diğer realiteyi oluşturmaktadır. Kamu yönetiminde ortaya çıkan sıkıntı ve sorunların çözümü için geliştirilen reform çalışmalarının ana eksenini kamu yönetiminde uzun bir dönem uygulanan klasik yönetim anlayışının olumsuzluklarından kaynaklanan sorunların giderilmesi çabası oluşturmaktadır.

Kamu yönetiminde Weber'in bürokrasi modeliyle uygulamada beklenen rasyonel işleyişin gerçekleşememesidurumu, pekçoksorunayolaçtığıiçineleştirilereuğramıştır(Eryllmaz,2004:208). $\mathrm{Bu}$ nedenle özellikle klasik anlayışın temelini oluşturan bürokrasi anlayışının neden olduğu sorunlar hedef alınarak, bürokrasi kaynaklı sorunlardan kurtulmak için başta özel sektörün kullandığı teknik ve metotlardan faydalanarak kamu yönetimi anlayışında yeni bir yönetim anlayışııın ortaya çıkarılması istenmektedir.

Dünyada ve Türkiye'de klasik yönetim anlayışının izlerinden kaynaklanan sorunlar incelendiğinde öncelikli olarak bürokrasi içerikli sorunların ön planda olduğu gözlenmektedir. Strateji kavramın özüne ters düşen durağanlık anlayışına sahip olan bürokrasi anlayışı değișen 
şartlara ve ihtiyaçlara göre hareket etme gücünü sınırlamaktadır. Çalışanların birer makine parçası olarak değerlendirildiği örgüt yapısı içerisinde çalı̧anların, söz sahibi olmamaları ve değişim içerisinde görüşlerine yer verilmemesi strateji olgusunun doğasına ters düşmekte, kamu kurumlarının gelişimine ve kendilerinden beklenen işlevleri yerine getirmelerine engel olmaktadır(Eryılmaz,2004:209).

Türk kamu yönetiminde de durum bu yöndedir. Kamu yönetiminin yapılanma ve işleyişinde tarihsel sürecin rolü başta olmak üzere kamu yönetiminde yaşanan kimlik krizi karşısında araştırmacı ve uygulayıcıların duruşu, kamu yönetimi üzerinde sosyal, kültürel, ekonomik ve politik etkenlerin rolü, bürokrasi kaynaklı sorunlar karşısında geleceğe dönük dersler çıkarılıp çıkarılamaması, yapılan reform çalışmalarında siyasetçilerin, sivil toplum kuruluşlarının, üniversite ve vatandaşların katılımı, kamu yönetiminde kurumların ve bireylerin karşılıklı güven ilişkisi, kamu yönetiminde eğitim içerikli güçlükler gibi çok sayıda durumun kamu yönetiminin temel sorunlarını oluşturduğu düşünülmektedir(Acar ve Öztaş, 2007:75-76).

Türk kamu yönetiminde temel sorunlar arasında aşırı merkeziyetçi yapılanma önemli bir sorun kaynağını oluşturmaktadır. Merkeziyetçilik, kamusal kaynakların başkent örgüt tarafından kullanılmasını ve yönetilmesini ifade etmektedir(Acar ve Sevinç,2005:21) Kamu yönetiminin, klasik, dişa kapalı, merkeziyetçi, statükocu, kırtasiyeci, hantal, sorumluluktan kaçan ve siyasal anlamda yozlaşan bir yapı halinde olması temel eleştiri noktalarını ve başlıca sorunlarını oluşturmaktadır(Karakaş ve Yaralı, 2004: 557). Kamu kurumlarında gözlenen katı hiyerarşik yapı, yetkilerin üst basamaklarda toplanması, gizlilik, siyasi/idari güç ile uzmanlık gücü arasında yaşanan çatışmalar, kuralların yoğunluğu, taktir yetkisinin daraltılması rekabetin yokluğu, kendi kendini yenileyememe ve dolayısıyla gelen verimsizlik kamu yönetiminin temel sorunlarını oluşturmaktadır(Eryılmaz, 2004:242).

Modern anlamda bir kamu yönetimi yapısının oluşabilmesi için karar verme süreçlerinde yerelleşme, yönetsel hiyerarşiyi azaltma, bürokratik performansı geliştirme, bütçe sürecini daha elverişli duruma getirme, daha iyi kamu hizmetini daha az maliyetle sağlama, stratejilerini hedefleyen yönetimde "kürek çekme değil dümen tutma" felsefesinin benimsendiği bir yapıya gidilmelidir(Özer,2005:39).Kamu yöneticilerinin strateji olgusunu kullanabilen stratejik düşünme niteliğine sahip liderlik vasfı taşıyan bir karakter sergilemesi kurum başarısı üzerinde ve kurumun karşı karşıya kaldığı sıkıntılardan kurtulması noktasında önemli bir yere sahiptir(Aktan, 2003:79).

\section{Kamu Yönetiminde Gelecek Endişesi}

Günümüz dünyasında çoğu ülkenin kamu yönetimi ürettikleri mal ve hizmetlerde kaliteyi, verimliliği, etkinliği ve hakkaniyeti temel hedefler olarak belirlemektedir. Bu hedeflere ulaşmak isteyen yönetimler, yeni metot ve teknik arayış içerisine girmektedir. Bu kapsamda da özellikle özel sektörde geliştirilen yöntemlerin kamu yönetimine aktarılmaya çalışıldığı gözlenmektedir. $\mathrm{Bu}$ amaca yönelik olarak örnek alınmaya çalışılan yaklaşımlardan bir tanesini stratejik yönetim anlayışı oluşturmaktadır. Bu anlayış ile kamu örgütlerinde uzun dönemli stratejiler geliştirilerek 
etkin bir yönetim anlayışına ulaşılması hedeflenmektedir(Güçlü,2003:81). Küreselleşme başta olmak üzere dünyada gözlenen hızlı teknolojik ilerlemeler, vatandaşların kamusal hizmetler karşısında artan talepleri kurumları, stratejik düşünmek zorunda bırakmaktadır. Yaşanan bu gelişmeler, kamu kurumlarının stratejik yönetim ve buna bağlı olarak stratejik planlama süreçlerine yönelmesini gerektirmektedir. Bu durum ise 1980'li yllardan önce sadece özel sektörde uygulama şansı bulan stratejik yönetim anlayışının günümüzde kamu sektöründe de uygulanmaya başlamasına yol açmıştır(Söyler,2007:103). Kamu yönetimi üzerinde kaynakların etkili ve verimli kullanılması yönündeki beklentiler, hizmet sunum standartlarının yükselişi, mevcut kaynaklarla ek külfetlere katlanmadan hizmet kalitesinin arttırılması yönündeki taleplerin karşılanmasını gerekli kılmaktadır (Barca ve Balcı, 2004:3). Bu nedenle kamu kurumlarının değişim karşısında tutunabilmeleri, gelecekte varlıklarını sürdüre bilmeleri içsel ve dışsal stratejik bilgi kaynaklarından faydalanmalarını zorunlu hale getirmektedir(Yıldırım, 2010:1313).

Kamu yönetimi üzerinde oluşan bu beklentiler, kamu yöneticileri başta olmak üzere birçok kişinin kurum yönetiminde stratejik bir yönetim anlayışının geliştirilmesine, kurumlarda geleceği öngörebilen bir vizyon oluşmasına yönelik çaba harcanmasını gerekli kılmaktadır. Bu nedenle de kamu yöneticileri için kurumun duruşu ve pozisyonunun belirlenmesi üzerinde etkileri bulunan strateji olgusu önemli bir niteliğe sahip olmaktadır(Poister vd,2010:3).

Kamu yönetiminde strateji olgusunun gündeme gelmesinde yeni kamu yönetimi yaklaşımının önemli bir yeri olduğunu söylemek mümkündür. Yeni kamu yönetimi anlayışı 20. yüzyılın sonuna doğru klasik kamu yönetimi anlayışının yerini post-bürokratik bir anlayışı içeren yeni bir paradigmaya bırakmasının bir sonucu olarak doğmuştur(O'flynn,2007:354). Yaklaşımın ortaya çıkmasındaki en büyük etken dönemin içinde bulunduğu ekonomik krizler karşısında kamu yönetiminin etkin ve verimli çalışamaması beraberinde kamunun hantallığı ve işlevsizliği tartışmalarının yaygınlaşmasıdır. Yeni kamu yönetimi yaklaşımının çıkış gerekçesi, önceki yaklaşımın ortaya çıkardığı problemlere daha gerçekçi çözümler sunabilmektir(Hughes,2003:44). Kamu yönetiminde dönüşümün girişimci bir anlayışla mümkün olabileceğinin gerekliliğinin sorgulandığı (Osberne and Gaebler, 1992:108) yeni kamu yönetimi anlayışı kapsamında bürokratik sorunlara çözümler aranarak kamu yönetiminde bir sıçrama yaşanması hedeflenmektedir. Kamu yönetiminin içinde bulunduğu sorunlara yeni bir anlayışla çözüm sunmaya çalışan yeni kamu yönetimi yaklaşımı, yönetimde bir felsefe değişikliğini ifade etmeye çalışmaktadır. Bu kapsamda küçük ama etkin devlet anlayışını kamu yönetimine hakim kılmak istemektedir. Bu amaçla yeni yaklaşımla kamu yönetiminde; a)hiyerarşik bürokrasiden çok piyasa mekanizmasına, b)müşteriye karşı sorumluluk bilincine, c)süreçlerden çok sonuçlara, d)hesap verme sorumluluğuna, e)kamu yönetimden ziyade işletme yönetiminin esaslarına, f) etkinlik, g)verimlilik, 1)ekonomiklik gibi değerlere yer verilerek klasik anlayışın eksiklerinin giderilmesi hedeflenmiştir(Özer,2005:225). Bu noktada da işletme yönetiminde uygulanan teknik ve metotların kamuda kullanılması amaçlanmıştır.

Stratejik bakış olgusunu bu kapsamda yeni kamu yönetimi yaklaşımı ile ilişkilendirerek ele almak mümkündür. Örgütün gelecek hedeflerine mevcut şartlar ve gelecekte karşılaşabileceği 
koşulların önceden görülerek bu yönde bir faaliyet sürmesini öngören stratejik bakış yeni kamu yönetimi ile ortaya konmaya çalş̧llan stratejik plan, performans yönetimi, bilgi yönetimi gibi teknik ve metotlarla paralel bir gelişim seyri izlemektedir. Kurumların sahip olacağ stratejik yönetim anlayışıyla, klasik yönetim anlayışına sahip olan bürokratik örgütlenme yapısının yerini çevreye duyarlı değişimi içinde barındıran bir yönetim anlayışına bırakması sağlanacaktır. Bu anlayış sayesinde kamu yönetiminin gelecek endişesi sorununa çözüm sunacağ düşünülmektedir(Yüksel,2004:44). Değişimin kaçınılmaz olduğu günümüzde kamu yönetiminin gelecek kaygısı duyması, değişimle birlikte gelen yaklaşım ve tekniklerden haberdar olması, bu teknik ve metotların kurumlarda benimsenmesi, kullanım şansı bulması, kamu yönetiminin gelecek endişesi taşımasını ve bu yönde bilinçli yönetici ve örgüt çalışanlarının varlığını gerekli kılmaktadır.

\section{Kamu Yönetiminde Yaşanan Sıkıntılara ve Gelecek Endişesine Çözüm Olarak Stratejik Bakış ve Vizyon}

Dünyada olduğu gibi Türkiye'de de kamu yönetimi küreselleşme karşısında mevcut yapılanmasıyla zamanın gereklerini ve toplumsal beklentileri karşılamada zorluk çekmektedir. Klasik anlayışın izlerinin hala birçok kurum işleyişinde belirgin olarak uygulanıyor olması, bürokratik anlayışın kurum yöneticileri ve çalışanları üzerinde sağladığı, sır ve gizlilikten kaynaklanan korumacı yapısı, değişim ve rekabete kapalı anlayışın kırılmasını engellemektedir. Kamu yönetiminde değișime, gelişime, rekabete kapalı anlayışın varlığı ve kurumların durağan yapısını muhafaza etmesi, çalışanlar ve yöneticilerin daha az çaba harcamasını daha az sorumlu olmasını sağlaması açısından onların lehine görünüşte bir katkı sağlamaktadır. Oysa toplum açısından ve ülke kalkınması açısından düşünüldüğünde kaliteden uzak etkin işlemeyen bir kamu yönetiminin toplum üzerinde halkın beklentilerinden uzak çok fazla sıkıntıya neden olacağı düşünülmektedir.

Kamu yönetiminde zamanın gereklerine uygun bir yönetim anlayışının gelişmesi, kamu yönetiminde yaşanan sıkıntıların giderilmesi, değişim olgusunun kurumlarda yerleştirilmesi, toplumsal beklentilerin göz önüne alınmasını ve bu yönde çalışmaların yapılmasını gerekli kılmaktadır. Bu nedenle kamu yönetiminde değişimi içeren gelişme ve rekabeti bünyesinde barındıran strateji olgusuna yer verilmesi gerekmektedir. Zaten dünyada gözlenen eğilim de bu yöndedir. Son elli yıldır strateji alanında yapılan çalışmaların geniş ve çeşitli çevrelerce artan bir seviyede ilgi ve destek bulduğu birçok alanda, uluslararası ilişkilerde, kamu yönetiminde, siyasette, vb disiplinlerde strateji olgusunun kullanımına yaygın bir şekilde yer verilmesinden anlaşılmaktadır(Barca, 2005:8). Bugün birçok ülkenin kamu yönetiminde, hukuksal, yapısal ve yönetsel bozukluk ve eksikliklerden kaynaklanan sıkıntılara rastlanılmaktadır. Özellikle yönetsel olanlar bu sıkıntılar içerisinde en büyük payı oluşturmaktadır. Bu sıkıntılar karşısında, stratejik planlama öncelikle iyi yönetimi hedeflemektedir. Stratejik planlama sayesinde yöneticilerin edineceği "stratejik düşünme ve davranma" özelliğinin kamu yönetiminin sorunlarını giderme konusunda çok sayıda faydasının olacağı düşünülmektedir(Yılmaz, 2003:72). 
Yirminci yüzyılın son çeyreğinden itibaren hızlı bir ivme kazanan bilgi toplumu, bilgi ve iletişim teknolojilerindeki baş döndürücü gelişmeler, mekan ve zaman engellerini ortadan kaldırarak bilgi yayılımını artırmıştır (Yıldırım, 2010: 1315). Yaşanan bu durum halkın kamu örgütlerinden beklentilerini daha fazla artırmış ve kamu örgütlerinin bilgi karşısında ve halkın beklentileri karşısında kayıtsız kalmasına neden olmuştur.

Bilgi yönetiminin bilinçli bir strateji olarak kamu yönetiminde kullanılması yeni bir olgudur(Yıldırım, 2010: 1322). Stratejik bakışın önemli bir unsurunu bilgi yönetimi oluşturmaktadır. Kamu yönetiminde bilginin yönetilmesi ve faaliyetlerinde kullanılması, bilgiye dayalı hizmet yeni bir fikir değildir. Bilgi yönetiminin kullanılması kamunun karşı karşıya kaldığı sıkıntıların aşılmasında bir araç olarak kullanılmaya çalışılmaktadır. Kamu yönetiminde bilgi yönetiminden etkin bir şekilde faydalanabilmek için ilk önce, yönetim felsefesinin değiştirmek gerekmektedir. Bu nedenle iyi bir stratejik planlama yapılmalı ve geleceği tahmin edebilen, ölçebilen, nicel verileri kullanıp yorumlayan, uzman planlamacılardan oluşan bir ekibin çalışmasına ihtiyaç duyulmalıdır(Karakaş ve Yaralı, 2004: 557). Rekabet, belirsizlik ve risklerle dolu, hızla değişen çevre koşullarında örgütlerin varlıklarını sürdürerek karlılıklarını artırabilmeleri için bilgi, başlı başına bir değer bir kaynak haline gelmiştir(Yıldırım, 2010: 1331).

Kamu yönetiminin geleceği öngörebilmesi, geleceği kurgulama boyutu, özü itibariyle, kamu kurumlarının şimdi nerede olduğundan hareketle gelecekte nerede olmak istediğine dair bir hedef belirlemesini ifade etmektedir. Stratejik yönetim anlayışını benimseyen kamu kurumlarında kurumların sadece günün sorunlarıyla ilgilenmemesi, geleceğin inşasına aktif biçimde katılması, gelecekteki güç kaynakları üzerinde yoğunlaşarak onlardan nasıl daha etkin bir şekilde yararlanabileceğini, önceden düşünerek yanıtlaması gerekmektedir(Barca,2004:17). $\mathrm{Bu}$ nedenle stratejik yönetim kapsamında yöneticilerin stratejik planların hazırlanması sürecine dikkat etmeleri gerekmektedir.

Genel manada strateji süreci, strateji oluşturma ve oluşan stratejiyi uygulama aşamasından oluşmaktadır. Bu süreç içerisinde süreci etkileyen altı alt faktörden bahsedilebilir. Kültür ve çevre strateji oluşturma üzerinde etkide bulunur iken organizasyon ve fonksiyonlar strateji uygulama aşamasını etkilemektedir. Yine bilgi ve kaynakların hem strateji oluşturma hem de stratejiyi uygulama aşamasında önemli etkilere neden olduğu düşünülmektedir(Tarabanis vd.,2001:992). $\mathrm{Bu}$ nedenle kurumlar strateji geliştirirken hem iç hem de diş faktörlerin etkilerini göz önünde bulundurmalıdırlar. Eğer yöneticiler yanlışs stratejiler izleyip planlama aşamasında yanlış bir yol takip ederlerse kurumun başarısı yerine kurumun hedeflerine ve amaçlarına ulaşılamaması gibi bir sonucun ortaya çıkması kaçınılmaz olmaktadır.

Kurumların strateji geliştirirlerken üzerlerinde durması gereken diğer bir nokta hiç kuşkusuz gerçeklikler ile stratejik planlar arasındaki ilişkidir. Bu kapsamda gerçeklik konusu üzerinden stratejik planlama sürecine felsefi ve teorik katkıları olan öğrenme okulunun konuya bakışını kısaca değerlendirmekte yarar vardır. "İlkinde başarılı olamadıysan tekrar tekrar dene" felsefesini savunan, betimsel okullar arasında görülen öğrenme okulu öngörücü okullara ciddi bir meydan okumayla gerçekçi bir akım oluşturduğu düşünülmektedir(Sarvan vd., 2003: 9091). Öğrenme okulunun diğer okullarda eksiliği tartışılan strateji geliştirme çalışmalarına bir 
gerçeklik getirmeye çalıştığı düşünülmektedir(Mintzberg vd, 2005: 229) Öğrenme okulunun varsayımları incelendiğinde geleceğin belirsiz olması, bilgi, kaynak, zaman yetersizliği ve kişilerin bilişsel sınırlılıkları gibi faktörlerden dolayı geleceğe yönelik tahminler doğrultusunda stratejiler planlamanın mümkün olmayacağı düşünülmektedir. Bu nedenle stratejilerin rasyonel şekilde planlanması organizasyonun gerçekleriyle örtüşmeyeceği düşünülmektedir. Stratejilerin zaman içinde uygulamada alınan bir takım kararlar doğrultusunda gelişeceği varsayılmaktadır. Stratejinin biçimlenmesi bir öğrenme süreci olarak meydana gelmektedir(Sarvan vd. , 2003: 94). Öğrenme okulu kurallar koymaktan ziyade betimleyici bir anlayışla strateji geliştirmeyi zamanla kendiliğinden gelişen bir öğrenme süreci olarak ele almaktadır (Bakoğlu ve Özcan, 2010: 63). Stratejiler geliştirilirken ve stratejik planlar hazırlanırken örgütün mevcut durumu dikkate alınmalı, kes kopyala anlayışı ile örgütle alakası olmayan stratejik kararlar alınmamalı örgüt doğası, gerçeklikler kapsamında adım adım izlenerek doğru hedeflere doğru kararlarla ulaşılmaya çalışılmalıdır.

Kurumların stratejik düşünme ve stratejik planlarla hayata geçirmeye çalıştıkları yönetim felsefesindeki değişimde vizyon olgusuna da önemli bir yer ayırdıkları görülmektedir. Toplumsal yaşamın birçok alanında gittikçe daha sık kullanım alanı bulan vizyon, önemi gün geçtikçe artan yönetsel bir kavram olarak karşımıza çıkmaktadır. Yönetim süreci içerisinde de kurumların vizyona sahip olmaları kurumsal amaçlara ulaşmalarında bir araç görevi görmektedir. Bu araç sayesinde vizyon sahibi kurum yöneticileri yönettiği kurumun amaç ve hedeflerinin kamuoyuna yansıtılmasına aracıllk etmektedir(Çetin,2009:96).

Vizyon kavramı Latince kökenli "videre" kelimesiyle gündeme gelen; anlamak, uyanık olmak, sezmek, fark etmek gibi anlamları taşıyan ve daha çok bilinenden hareketle bilinmeyeni ifade eden bir bakışı ifade etmektedir(Yüksel vd.,2005:263-264). Vizyon kurumların geleceğe yönelik örgütsel kültürünü, dünya görüşünü, gelecek perspektifini, yöneticilerin evren algısını, vs. belirleyen bir işlev görmektedir(Barca,2004:16).Vizyon, kurumların hedeflerini açlk bir şekilde belirleyen, hedeflerin sade anlaşılır ve erişilebilir olmasını sağlayan, stratejilerin geliştirilmesinde kılavuz görevi gören bir işleve sahiptir(Bütüner,2004:15). Kamu kurumlarının geleceğe yönelik hedeflerine ulaşmasında ve kurumun geleceğinin şekillendirilmesinde üst düzey yöneticilerin sahip oldukları vizyonlarının belirleyici bir faktör olduğu düşünülmektedir(Yüksel vd.,2005:265). Vizyon kavramı ile birlikte anılan ve birbirinin yerine sıkça kullanılan bir diğer kavram ise misyondur.

Kurum misyonu kurumun faaliyetleri süresince uygulamaya çalıştı̆̆ stratejik planlama kapsamında yapılacak faaliyetleri yönlendirmede kullanılacak bir kılavuz görevi görerek kurumun stratejisine uygun bir yol izlemesine yardımcı olmaktadır(Özgül,2004:215). Kurum sahip olduğu misyonla kurumların hangi hizmetleri nerede ve nasıl sunacağı, kurumun hizmet felsefesinin ne olacağı, kurumun hangi değerlere sahip olacağı ve kurumun diğer kurumlardan farkının ne olacağının sınırları çizilmek istenmektedir(Çetin, 2009: 98).

Vizyon kavramıyla misyon arasındaki bağlantıyı vizyonun, "nereye gitmek istiyoruz?" sorusuna cevap vermesi ve misyonun da verilen cevaba ulaşmak için "şimdi nelerin, nasıl yapılması gerektiği” konusuna verilen yanıt şeklinde değerlendirmek mümkündür(Kılıç ve 
Erkan,2006:81). Vizyon kavramı geleceği öngören, gelecek eğilimli bir kavram olduğu için günümüz yöneticilerini de doğrudan ilgilendiren ve yöneticilerinde sahip olması gereken bir nitelik göstermektedir(Yüksel,2004:80). Stratejik yönetim sayesinde örgütler kurum misyonunu gerçekleştirerek kurumun çevreyle olan ilişkilerinin geliştirilmesine katkı sağlanacağ düşünülmektedir (Zeqiri,2010:1).

Stratejik bakış, kamu kurumlarında yöneticilerin kendini, sistemi, amaçları ve kaynakları değerlendirip uygun karar almasını sağlayan bir araçtır. Yöneticiler bu aracı kullanarak; kurumun geleceğine yön verecek olan fikirler için tutarlı bir çerçeve oluşturmak, firsat ve tehditleri değerlendirmek, kurumun güçlü ve zayıf yönlerini belirlemek, çeşitli stratejilerin test edileceği kriterleri belirlemek, trendlerin izlenmesini sağlamak, kişileri düşünceye sevk etmek, kısa ve uzun vadeli kararların uyum içinde olmasını sağlamak, optimum kaynak tahsisini gerçekleştirerek kurumun amaçlarına istenilen düzeyde ulaşmayı hedeflerler(Gürer,2006:95). Ancak stratejik bakışın kamu yönetiminde uygulanmasını zorlaştıran bazı güçlüklerinde göz ardı edilmemesi ve bu yönde önlemlerin alınması da gerekmektedir.

Kamu yönetiminde uygulanmaya çalışlan stratejik yönetim anlayışı kamu yönetiminin sektörel ve işlemsel yapısından ötürü bazı sıkıntılarla karşı karşıya kalmaktadır. Kamu sektörünün ürettiği malların "kamu hizmeti" niteliği taşıyor olması, hizmet sunumunda kar amacı güdülmüyor olması, rekabet faktörünün bulunmaması, aşırı merkeziyetçi yapı gibi sektörel engellerin yanı sıra; stratejik kararlar alınmasının eski alışkanlıklar nedeniyle uzun zaman alması, iş ve girdi-çıktı analizlerinin yapılmaması, stratejik hedeflere yeterli kaynak ayrılmaması, performans değerleme tekniklerinin olmaması, kamu sektöründe toplam kalite yönetimi, performans yönetimi, insan kaynakları yönetimi gibi stratejik yönetim sürecini destekleyecek yeni teknik ve anlayışların uygulanmaması sıkıntıların başlıca nedenlerini oluşturmaktadır (Söyler, 2007:113).

Kamu yönetiminin bu sıkıntılarından kurtulması halinde kamu yönetiminin gelecek hedeflerine ulaşmasında emin adımlarla ilerleyeceği ve halkın beklentilerine en iyi şekilde cevap vereceği düşünülmektedir. Bu nedenle kamu yönetiminde etkin, işlevsel bir yönetim için stratejik bakış olgusunun kurumun hedef ve amaçlarının belirlenmesinden bu amaçlara ulaşılıncaya kadar gözden geçirilerek uygulanması gerekmektedir. Kurumların stratejik bir anlayışa sahip olması da kurum yöneticilerinin stratejik düşünebilen kararlarını bu yönde alan vizyon sahibi yöneticiler tarafından idare edilmesine ve kurumda bu yönde bir iklimin yerleștirilmesine bağlı olduğu unutulmamalıdır.

\section{Sonuç}

Devletin ortaya çıktığı ilk günden beri kamu yönetimi, taşıdığı misyon gereği halkın beklentilerini en iyi şekilde karşılama arzusu içinde olmuştur. Kamu kurumlarının temel amaçları incelendiğinde; topluma en iyi hizmeti en verimli ve en etkin şekilde sunacak stratejik bir yönetim yapısına ulaşma hedefi taşıdıkları görülmektedir. Bu amacın yerine getirilmesi kamu yönetiminin zamanın gereklerini yerine getirmesi ile mümkün olmaktadır. Bu nedenle kamu 
yönetiminin gelecekte etkin ve verimli bir yönetim sunarak halkın beklentilerini karşllamaya devam edebilmesi küreselleşme ve bilgi teknolojileriyle ortaya çıkan değişim karşısında kendine yer bulmasıyla mümkün olacaktır.

Özellikle günümüz şartları içerisinde kamu yönetimi ele alındığında küreselleşme olgusu başta olmak üzere birçok faktörden ötürü kamu yönetiminin görev yükünün ve kendisinden beklenen işlevlerin artığı ve değiştiği gözlenmektedir. Bilgi çağı olarak adlandırılan günümüzde, kamu yönetiminin kaliteli ve nitelikli bir hizmet sunma anlayışına sahip olması dünyada gözlenen değişime ayak uydurmasıyla sağlanacaktır. Kamu yönetiminin, halkın beklentilerine cevap veremez hale gelmesi, durağan, işlevsel olmayan katı bürokratik yapısı, rekabete ve yeniliğe kapalı durumundan kaynaklanan sorunları ve gelecek kaygısının önlenmesi de bunu gerekli kilmaktadır.

Kamu yönetiminde klasik yönetim anlayışından kaynaklanan sorunların giderilmesinde özel sektörde yaygın bir şekilde kendine yer bulan stratejik düşünme ve stratejik yönetim ilke ve tekniklerinden kamu yönetiminde de faydalanılması gerekliliği, özellikle 1980'li yıllardan itibaren klasik yönetim anlayışına alternatif olarak ortaya konmaya çalışılan yeni kamu yönetimi anlayışı kapsamında ele alınmaktadır. Kamu yönetiminin bu yöndeki beklentileri karşılaması, içinde bulunduğu mevcut doğası ve geçmişinden günümüze taşıdığı klasik yönetim anlayışından kaynaklanan özelliklede bürokrasi kökenli sıkıntılardan kurtulmasını gerekli kılmaktadır. Kamu kurum ve kuruluşlarının daha nitelikli hizmet sunması için bu kurumların yeni stratejiler geliştirmesine ve bu amaçla yeni teknik ve metotlardan yararlanmasını zorunlu hale getirmektedir.

$\mathrm{Bu}$ nedenle çıkış menşeine bakıldığında önceleri askeri nitelikli bir kullanım alanına sahipken günümüzde çok farklı alanlarda kullanılan bir kavram olarak karşımıza çıkan strateji/ stratejik bakış olgusunun kamu yönetiminde de içselleşmesi gerekmektedir. Kamu yönetiminde kalite ve mükemmellik arayışının her gecen gün artığı günümüzde, vatandaşların bu yöndeki beklentilerine stratejik yönetim anlayışının kamu yönetiminde yaygınlaştırılmasıyla ulaşılacağı düşünülmektedir. Kamu yönetiminin bu hedeflere ulaşmasıysa kamu yönetimine stratejik bir iklim kazandıracak vizyon sahibi yöneticileri gerekli kılmaktadır. Yöneticilerin örgüt yönetiminde alacakları kararların stratejik nitelikli olması gelecekte oluşabilecek durumlar karşısında hazırlıklı olması, kamu kurumlarının temel hedeflerine ulaşmasında ve bu kapsamda halkın beklentilerine yerinde cevap verebilecek bir yönetim anlayışının ortaya çıkmasında önemli bir yere sahip olacaktır.

Kamu yönetiminde stratejik bakışın yerleşmesinde ilk adımı, kurumun mevcut durumunun iyi analiz edilmesi oluşturmaktadır. Kurumun mevcut durumu, eksileri, mevcut değerleri tespit edildikten sonra, örgütün amaçları ve hedefleri doğrultusunda ne yapılması gerektiğine karar verilmelidir. İlerleyen aşamalarda alınan kararlar ve planlar ortaya çıkabilecek yeni durumlar karşısında gözden geçirilerek tekrar revize edilmelidir.

Değişimin kaçınılmaz olduğu günümüzde kurumların yönetiminde mevcut/olası koşullar değerlendirilerek, örgüt misyonu ve vizyonu çerçevesinde gelecek analizleri yapılmalı; bu 
kapsamda kamu yönetiminin çağın gerisinde kalmadan hizmet sunumu ve amaçları çerçevesinde diğer sektörlerle rekabet edebilir duruma gelmesi; stratejiler geliştirmesi ve bu yönde bir yönetim anlayışına bağlı kalması ile mümkün olabilecektir.

$\mathrm{Bu}$ konuda öncelikle kamu yöneticilerine, kurum çalş̧anlarına ve beraberinde kamu hizmetinden faydalanan halka önemli görevler düşmektedir. Kurumun amaçlarının belirlenmesinde, hedeflere ulaşacak araç ve gerecin seçiminde, kullanılmasında, karar ve işlemler üzerinde söz sahibi olan yöneticilerin geleceği öngörebilen liderlik özelliği taşıyan idareci ve çalışanlardan oluşması gerekmektedir. Bu kapsamda örgüt yöneticileri ve kurum çalışanlarına stratejik düşüne bilme yeteneği kazandırmak amacıyla gerekli eğitimler ve motive edici destekler sunulması gerekmektedir. Yöneticiler, çalışanlar ve halkın kamu yönetimine olan bakışı, kamu yönetiminden beklentileri, kamu yönetiminin gelecek inşasında stratejik bakışı bu nedenle çok daha önemli bir yere taşımaktadır. 


\section{Kaynakça}

Acar, Ali ve İsmail Sevinç (2005) "1980 Sonrası Türk Kamu Yönetiminin Merkez Örgütlerinde Yapılan Reform Çalışmaları” Selçuk Üniversitesi SBE Dergisi, Sayı13, s.19-37.

Acar, Muhittin ve Nail Öztaş (2007) "Kamu Yönetimi Disiplininde Temel Soru(n)lar Tartışması ve Türkiye Açısından Bir Deneme” Şinasi Aksoy ve Yılmaz Üstüner (Editör), Kamu Yönetimi Yöntem ve Sorunlar, Ankara: Nobel Yayın Dağıtım.

Akçay, Ahmet (2009) “Kamuda Stratejik Plan Amaçlarının Gerçekleştirilmesine Yönelik Değerlendirme ve Denetim Modeli” TUBAV Bilim Dergisi, Cilt:2, Sayı:1, s.29-45.

Aktan, Coşkun Can (2003) Değişim Çağında Yönetim, İstanbul: Sistem Yayıncılık.

Aktan, Coşkun Can (2008) "Stratejik Yönetim ve Stratejik Planlama”, Çimento/İşveren. Temmuz-Ağustos 2008., s.1-21.

Bakoğlu, Refika ve Esra Dinç Özcan (2010) “İşletme Düzeyinde Strateji Paradokslarının Mintzberg’in On Stratejik Yönetim Okulu Açısından Değerlendirilmesi”, Öneri, Cilt 9, Sayı 34, s.57-69.

Barca, Mehmet (2005) “Stratejik Yönetim Düşüncesinin Evrimi: Bilimsel Bir Disiplinin Oluşum Hikayesi”, Yönetim Araştırmaları Dergisi, Cilt 5, Sayı 1, s.7-38

Barca, Mehmet ve Asım Balcı (2004) “Kamu Politikalarına Nasıl Stratejik Yaklaşılabilir?”, Sakarya Üniversitesi İİBF Tartışma Metinleri, 2004/4, s.1-31.

Barca, Mehmet, Döven, M. Said ve Taşkın, Kamil (2006) Uluslararası Pazarlarda Türk Gıda Sektörünün Rekabet Gücü ve İhracatta Aranan Kriterler/Karşılaşılan Engeller, İstanbul: İTO Yayınları, Yayın No: 2006-24.

Bircan, İsmail (2002) “Kamu Kesiminde Stratejik Yönetim ve Vizyon”, Planlama Dergisi, Özel Sayı (DPT’nin Kuruluşunun 42. Yıl1), s.11-19.

Bütüner, Hakan (2004) Stratejik Yönetim: Neden, Nasıl?, İstanbul: Rota Yayınları.

Bryson, John, M. (1995) Strategic Planning for Public and Nonprofit Organizations, San Francisco: JosseyBass Publishers.

Bryson, John M., Frances S. Berry, and Kaifeng Yang (2010) “The State of PublicStrategic Management Research: A Selective Literature Review and Set of Future Directions", The American Review of Public Administration, XX(X), p.1-27.

Bryson, John, M. (2011) Strategic Planning for Public and Nonprofit Organizations: A Guide to Strengthening and Sustaining Organizational Achievement, San Francisco: Jossey-Bass Publishers, Fourth edition.

Çetin, Sefa (2009) “Vizyon Yönetimi”, Selçuk Üniversitesi Sosyal Bilimler Enstitüsü Dergisi, Sayı 22, s.95-103

Dess, Gregory G, and Alex Miller (1993) Strategic Management, McGraw-Hill International Editions.

DPT (2006) Kamu İdareleri İçin Stratejik Planlama Kılavuzu, 2. Sürüm.

Eryılmaz, Bilal (2004) Kamu Yönetimi, İstanbul: Erkam Matbaası.

Genç, Fatma Neval (2009) “Türk Kamu Yönetiminde Stratejik Planlama”, Dumlupınar Üniversitesi Sosyal Bilimler Enstitüsü Dergisi, Sayı 23, s.201-211.

Güçlü, Nezahat (2003) “Stratejik Yönetim”, G.Ü. Gazi Eğitim Fakültesi Dergisi, Cilt 23, Sayı 2, s.61-85.

Gürer, Harun (2006) "Stratejik Planlamanın Temelleri ve Türk Kamu Yönetiminde Uygulanmasına Yönelik Öneriler”, Sayıştay Dergisi, Sayı 63,s.91-105.

Gürpınar, Koray ve M. Said Döven (2007) "Stratejik Yönetim Perspektifinden Türk Mobilya Sektörünün Rekabet Durumunun Analizi ve Değerlendirilmesi”, Afyon Kocatepe Üniversitesi İktisadi ve İdari Bilimler Fakültesi Dergisi, Cilt 9, Sayı 1, s.173-190. 
Hughes Owen E. (2003) Public Management and Administration, New York: Palgrave Macmillan, Third Edition.

Kaplan, Robert S. ve David P. Norton (2009) Balanced Scorecard, Şirket Stratejisini Eyleme Dönüştürmek, (Çev: Serra Eğeli), İstanbul: Sistem Yayıncılık.

Kaplan, Robert S. ve David P. Norton, (1996) Translating Strategy into Action: The Balanced Scorecard, Boston: Harvard Business School Press.

Karakaş, Bülent ve Aysun Yaralı ( 2004) "Kamu Yönetiminden Bilgi Yönetimine”, 3. Ulusal Bilgi, Ekonomi ve Yönetim Kongresi, 25-26 Kasım 2004, Eskişehir.

Kılıç, Mustafa ve Volkan Erkan (2006) "Stratejik Planlama ve Dengeli Performans Yönetimi Yaklaşımları Bir Arada Olabilir Mi?” Gazi Üniversitesi Ticaret ve Turizm Eğitim Fakültesi Dergisi, Sayı 2, s.77-93.

Luecke, Richard (2008) Strateji, (Çev: Turan Parlak), İstanbul: Türkiye İş Bankası Kültür Yayınları.

Mintzberg Henry, Bruce Ahlistrand and Joseph Lampel (2005) Strategy Safari: A Guided Tour Through The Wilds of Strategic Management, New York: Free Press.

Nasi, Greta and Francesca Frosini (2010) "Vision and Practice of E-Government: An Empirical Study", Financial Accountability \& Management, 26(1), p.85-101.

O’flynn Janine, (2007) "From New Public Management to Public Value: Paradigmatic Change and Managerial Implications", The Australian Journal of Public Administration, Vol. 66, No. 3.

Osborne, David and Gaebler, Ted (1992) Reinventing Government, New York: Penguin Book USA. Inc.

Özer, M. Akif (2005) “Günümüzün Yükselen Değeri: Yeni Kamu Yönetimi”, Sayıştay Dergisi, Sayı 59, s.346.

Özer, M. Akif, (2005) Yeni Kamu Yönetimi Teoriden Uygulamaya, Ankara: Platin Yayınları.

Özgür, Hüseyin (2004) “Kamu Örgütlerinde Stratejik Yönetim”, Muhittin Acar ve Hüseyin Özgür (Editör), Çă̆daş Kamu Yönetimi II Konular Kuramlar Kavramlar, Ankara: Nobel Yayın Dağıtım.

Poister, Theodore H., David W. Pitts and Lauren Hamilton Edwards (2010) "Strategic Management Research in the Public Sector: A Review, Synthesis, and Future Directions” The American Review of Public Administration, $\mathrm{XX}(\mathrm{X}), \mathrm{p} .1-24$.

Poister, H. Theodore (2010) “The Future of Strategic Planning in the Public Sector: Linking Strategic Management and Performance”, Public Administration Review, December 246-254.

Sarvan Fulya, Eren Durmuş Arıcı, Janset Özen, Bahattin Özdemir ve Ebru Tarcan İçigen (2003) "On Stratejik Yönetim Okulu: Biçimleşme Okulunun Bütünleştirici Çerçevesi”, Akdeniz İ.İ.B.F. Dergisi (6) $73-122$.

Söyler, İlhami (2007) “Kamu Sektöründe Stratejik Yönetim Uygulanabilir mi? (Engeller/Güçlükler)” Maliye Dergisi, Say1 152, s.103-115.

Tarabanis, Konstantinos, Vasilios Peristeras, Garyfallos Fragidis (2001) "Building An Enterprise Architecture for Public Administration: A High-Level Data Model for Strategic Planning”, Global Co-Operation in the New Millennium The 9th European Conference on Information Systems Bled, Slovenia, June 27-29, 2001.

Yıldırım, Murat (2009) "Kamu Yönetiminde Bilgi Yönetiminin Gerekliliği Üzerine Bir İnceleme" Uluslararası İnsan Bilimleri Dergisi, Cilt 7, Sayı 1, s.1312-1334.

Yılmaz, Kutluhan (2003) "Kamu Kuruluşları İçin Stratejik Planlama Uygulaması" Sayıştay Dergisi, Sayı 50-51, s.67-86.

Yüksel, Fatih, Osman Çevik ve Kadir Ardıç (2005) “Belediye Başkanlarının Vizyon Ölçümlerine İlişkin Bir Araştırma: Belde Belediyeleri Örneği”, Atatürk Üniversitesi İİBF Dergisi, Cilt: 19, Sayı 2, s.263-277.

Yüksel, Fatih (2004) Çağdaş Kent Yönetimi ve Yönetici Vizyonu, Ankara: Detay Yayıncılık. 
Yüzbaşığlu, Nedim (2004a) "İ̧̧letmelerde Stratejik Yönetim ve Planlama Açısından Stratejik Maliyet Yönetimi ve Enstrümanları", Selçuk Üniversitesi SBE Dergisi, Sayı 12, s.387-410.

Yüzbaşığlu, Nedim (2004b) 2000'li Yıllarda Strateji ve Planlama, Konya: Çizgi Kitapevi, Birinci Baskı.

Zeqiri, Izet (2010) "A Theoretical Overview of the Interactions between Entrepreneurship and Strategic Management” Munich Personal RePEc Archive MPRA, Paper No. 21943, s.1-9. http://mpra.ub.unimuenchen.de/21943/ (Erişim tarihi 12.04.2012). 